\title{
Some Further Studies of Gifted Children
}

\section{Elizabeth Cleveland}

To cite this article: Elizabeth Cleveland (1921) Some Further Studies of Gifted Children, The Journal of Educational Research, 4:3, 195-199, DOI: 10.1080/00220671.1921.10879196

To link to this article: $h$ ttp://dx.doi.org/10.1080/00220671.1921.10879196

册 Published online: 15 Dec 2014.

Submit your article to this journal 저

Q View related articles $\longleftarrow$ 


\section{SOME FURTHER STUDIES OF GIFTED CHILDREN}

Elizabeth Cleveland

Supervisor of Girls' Activities, Delroit Public Schools, Detroit, Michigan

Having established enough seventh- and eighth-grade classes for gifted children to serve most of the city of Detroit, and having arranged a satisfactory system of testing those who enter and of following up those who leave, we feel we have made a worth while beginning in the special training of the most promising. But we are still looking with curiosity and awe at the impressive group we have brought together, trying to discover "how they got that way" and what we had better do about it.

In the months between March and June, 1920 we made some special studies of our three "special advanced" classes, comparing them with a control group of normal pupils in the same schools as to health, nationality, home conditions, types of reading and recreation, amount of travel, and vocational and educational plans.

The health studies were made with 140 pupils and with an equal number of control pupils of the same age in the same schools. Although we were unable to arrange for a thorough physical examination of each pupil, we could at least, with the assistance of our physical training department, measure weight and height and make a rough estimate of general physical condition. Of course, compared with other pupils of the same grade, pupils of the special group are likely to be smaller, because they are younger. Many of them come from homes where health is intelligently looked after, and they show the effect of refreshing sleep, proper food, fresh air, and exercise. In comparing a group of gifted children with a normal group we had always received an impression of more complete physical fitness in the former. This is expressed in posture, in nervous control, and in a general look of contentment and well-being. There are fewer wandering eyes, fewer open mouths, fewer restless hands. Even taking into account the interest in work specially and skillfully adapted to their ability, these children show a poise and alertness that seem to be due, at least partly, to physical causes. According to the standards furnished by the Bureau of Education at Washington, 
we found 114 of the special group against 82 of the control group to be within ten pounds of the proper weight for their height. The teachers' estimates of general health showed no striking differences between the groups. This evidence, so far as it goes, seems to refute the old idea that the brilliant mind is usually found in the unhealthy body.

In questioning the pupils as to nationality we went back to their grandparents. For 114 children in the control group there were 176 reports as to the nationality of grandparents and in the special advanced group 222 .

The distribution of nationalities is shown in Table I.

TABLE I. NUMBER OF GRANDPARENTS OF INDICATED NATIONALITIES

\begin{tabular}{|c|c|c|c|}
\hline & Nationalities & $\begin{array}{l}\text { Control } \\
\text { Group }\end{array}$ & $\begin{array}{l}\text { Gifted } \\
\text { Group }\end{array}$ \\
\hline & American $\ldots \ldots \ldots \ldots \ldots \ldots \ldots$ & 97 & 90 \\
\hline & English. .................... & 13 & 28 \\
\hline & Canadian...$\ldots \ldots \ldots \ldots \ldots \ldots$ & 27 & 15 \\
\hline & German $\ldots \ldots \ldots \ldots \ldots \ldots \ldots$ & 12 & 36 \\
\hline & Scotch $\ldots \ldots \ldots \ldots \ldots \ldots \ldots \ldots$ & 17 & 23 \\
\hline & 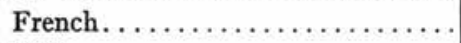 & 3 & 11 \\
\hline & Irish $\ldots \ldots \ldots \ldots \ldots \ldots \ldots \ldots$ & 5 & 16 \\
\hline & Swiss. . . . . . . . . . . . . . . & 1 & .. \\
\hline & 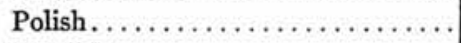 & 1 & .. \\
\hline & Swedish................... & . & 1 \\
\hline & 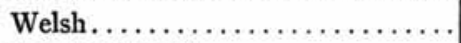 & $\ldots$ & 1 \\
\hline & Newfoundland............... & .. & 1 \\
\hline & Total $\ldots \ldots \ldots \ldots \ldots \ldots \ldots$ & 176 & 222 \\
\hline
\end{tabular}

This report is, of course, not a safe basis of generalizing, yet it suggests some interesting lines of investigation. The English, Scotch, and Irish usually make a good showing and some teachers have attributed this to the common language. But the French and German make a still better showing and the Canadians not so good. In a general way we have always observed that the children of some nations are bright and some dull; that RussianJews are quick to learn and that Poles are slow. But what determines the fiber of a group that has lived for centuries in the same conditions? Is it the inner structure or the outward circum- 
stances? If we knew we might begin to modify in some respects our complacent uniformity.

In another connection when studying a group of girls retarded for various reasons (other than mental deficiency) we had found the most marked difference from the control group in their fathers' occupations, indicating social rather than mental or physical causes for their retardation. Furthermore our first groups of gifted children, selected according to the judgment of teachers and principals, had shown a decided majority of pupils whose fathers were in responsible business positions or in the professions - pupils who belonged to the prosperous, or at least to the comfortable classes. Perhaps their good English, easy manners, and general sophistication impressed their teachers as superior intelligence. At any rate we were surprised to find that in the present study this distinction tended to disappear. When the gifted children were selected according to the results of the tests the occupations of their parents were chiefly remarkable for their great diversity.

When it came to tastes and standards of living, as shown in the kind of reading and recreation and in plans for education there was a distinct difference between the groups. The pupils were asked to name their favorite books, which were classified as inferior, average, and superior. Dime novels, silly sentimental tales, the "Elsie" and "Polyanna" sort of books were considered inferior. Books read for information, books that appeal through subject rather than style, ordinary modern novels, were classed "average." Well-written history, poetry, the finest fiction, were called "superior." The results are shown in Table II.

TABLE II. DISTRIBUTION OF PUPILS ACCORDING TO THE READING PREFERENCES

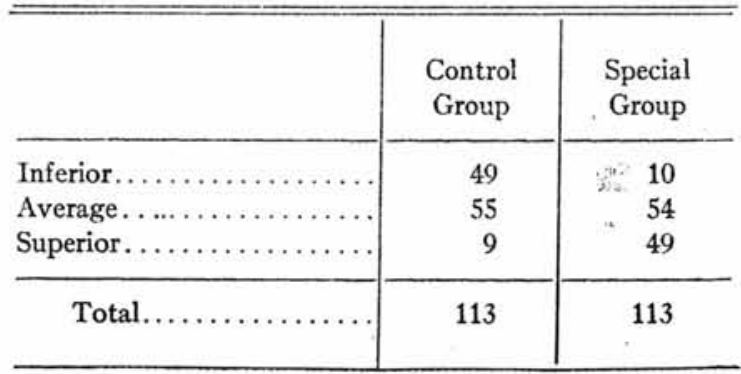


It seems obvious enough that they appreciate because they are bright. But can it also be said that they are bright because they appreciate? Would they have passed the tests as they did had they not read so much and so discriminatingly? Certainly the brighter ones even at this age have the vision of higher education. Sixty-two of the gifted group were already planning for college. Perhaps also the intelligence is sharpened by experience of the world. Forty-eight of the gifted group against 36 in the control group had travelled considerably.

At the end of the year a report was made on the pupils who were found in any way unsatisfactory, with the teachers' comments on the cause. We found 22 out of 160 reported weak, 15 of these in one subject only, 14 of these 15 in Latin and 13 of them in one school. Fifteen of the 22 were in the vIIB (the beginning class), six in the VIIA, one in the vIIIB, and none in the virIA. Only four pupils were reported generally weak. The main cause of the difficulty in the case of 11 pupils was reported as lack of concentration and application, which of course need not indicate that the testing was at fault. The problem is to develop these powers.

There were only four whom the teachers considered lacking in ability. These will be referred back to the testing department for special study.

A follow-up report on 47 high-school pupils formerly members of gifted groups shows the following results:

Superior work (almost all 1's and 2's) $\ldots \ldots \ldots \ldots \ldots \ldots \ldots$

Satisfactory (2's or 2's and 3's) ...................

Unsatisfactory (3's or 4's in more than one subject)..... 4

A report from a Latin class, six of whose members were formerly in gifted groups and most of whom had had the same teacher since the beginning of their course, showed the following averages as results of their mid-semester examinations.

Average of class .........................66

Average of five from gifted group ${ }^{\mathrm{a}} \ldots \ldots \ldots \ldots \ldots \ldots \ldots .60$

Average of class exclusive of five from gifted group........62

All these reports are suggestive so far as they go, but much more observation and experiment is needed. We plan to continue the recording along the lines indicated above and particularly to extend our work in physical measurement. Our first

${ }^{a}$ One best student absent. 
classes are just graduating from high school and we hope to follow the progress of each individual in college or in vocations. So that while we have made no progress in the remoter problems of determining causes, we can at least begin to measure the effects of our methods and make modifications accordingly. 